\title{
ISAIAH 36-39: RETHINKING THE ISSUES OF PRIORITY AND HISTORICAL RELIABILITY
}

Authors:

Joel E. Anderson ${ }^{1}$

Pieter M. Venter

\author{
Affiliations: \\ ${ }^{1}$ Department of Old \\ Testament Studies, \\ University of Pretoria, South \\ Africa
}

Correspondence to:

Joel E. Anderson

e-mail:

joelando11@yahoo.com

Postal address:

105 Fox Run, Florence,

Alabama, 35633, USA

\section{Keywords:}

Isaiah; invasion of

Sennacherib; Immanuel

prophecy; Mannaseh;

Hezekiah

Dates:

Received: 15 July 2008

Accepted: 18 Nov. 2008

Published: 08 June 2009

How to cite this article: Anderson, J.E. \& Venter, P.M., 2009, 'Isaiah 36-39: Rethinking the issues of priority and historical reliability', HTS Teologiese Studies/Theological Studies 65(1), Art. \#123, 7 pages. DOI: 10.4102/hts.v65i1.123

\section{This article is available} at:

http://www.hts.org.za

\section{Note:}

This article is a reworked version of a section of the $\mathrm{PhD}$ dissertation 'Isaiah 7:14: Identity and function within the bookend structure of Proto-Isaiah', prepared under the supervision of Prof. Dr P.M. Venter, Department of Old Testament Studies, Faculty of Theology, University of Pretoria, 2008.

\section{(C) 2009. The Authors.} Licensee: OpenJournals Publishing. This work is licensed under the Creative Commons Attribution License.

\section{ABSTRACT}

Isaiah 36-39 is a coherent literary unity that both holds priority over II Kings 18-20 and reflects a historically reliable interpretation of the events surrounding Sennacherib's invasion. On a literary level, Isaiah 36-39 shows itself to be a vital piece of the overall literary structure of ProtoIsaiah in that it highlights the fulfilment of Isaiah's initial Immanuel prophecy in chapters 7-12. The historical occasion for the writing of Isaiah 36-39 is early on during the reign of Manasseh, when opinion in Judah would have been divided over how to interpret the historical events surrounding Sennacherib's invasion. Isaiah 36-39, therefore, sought to vindicate Hezekiah as a faithful and righteous king, Isaiah as a true prophet and YHWH as the one true God, in contrast to Manasseh's policy changes that clearly reflected his opinion that Hezekiah was a foolish king, Isaiah was a false prophet and YHWH was not powerful enough to protect Judah.

\section{INTRODUCTION}

Isaiah 36-39 and its parallel text in II Kings 18-20 have proven to be very problematic for biblical scholars for quite some time. These accounts, in which we are told about the invasion of Sennacherib, Hezekiah's illness and recovery and the visit of envoys from Babylon to Hezekiah, have been the subject of numerous exegetical questions. There is the question of priority: Does one account hold priority over the other, or do both accounts borrow from an earlier source? There is the question of the literary unity of both accounts. There is the question of the date of composition and purpose of both accounts. Finally, there is the question of the historical reliability of the biblical account of Sennacherib's invasion. The prevailing opinion concerning these questions has been that (a) II Kings 18-20 holds priority over Isaiah 36-39; (b) the text found in these passages is a heavily (and somewhat sloppily) redacted conglomeration of three earlier sources, resulting in the text not having a clear literary unity; (c) its composition took place long after the events it describes, most likely during the exile; and (d) it is a fictional account of Hezekiah's reign written by later redactors who intentionally rewrote history to suit their theological agenda.

In this article, we will challenge each one of these positions and will attempt to show that it is more likely that (a) Isaiah 36-39 holds priority over II Kings 18-20; (b) the text not only has literary unity but also is vital to the overall structure of Proto-Isaiah; (c) a more probable date of composition for the text in question is during the reign of Manasseh, shortly after the death of Hezekiah, and thus its purpose was to address crucial issues that stemmed from the fallout of Sennacherib's invasion; and (d) while no doubt written from a distinctly theological point of view, it is by and large a historically reliable account of the events during Hezekiah's reign.

\section{An overview of the prevailing scholarly position}

Wilhelm Gesenius was the first scholar to argue that Isaiah 36-39 was essentially an attempt to smooth out the difficulties within the earlier II Kings text. He argued that while II Kings 18:13-20:19 fitted in with the overall structure of II Kings, Isaiah 36-39 did not seem to fit in with the overall structure of Isaiah. He noted that since the book of Isaiah continued to develop after II Kings was completed, it was more likely that Isaiah 36-39, as stated by H.H. Rowley, was 'taken by the compiler of the book of Isaiah from the account in Kings' (1963:100). This view has been echoed by countless scholars. Raymond Person (1999:374), for example, states that Isaiah 38:9-20, a passage unique to Isaiah, 'is generally assumed to have been added when the Kings passage was inserted into its Isaianic context'. Peter Ackroyd's (1984:247) belief that II Kings holds priority over Isaiah also can be seen when he states that Isaiah 36-39 is a 'partially deviant text'.

Consequently, the view that II Kings 18-20 holds priority over Isaiah 36-39 has caused these parallel texts to be viewed in different ways. The two issues most commonly associated with II Kings 18-20 have been (a) the apparent redaction of sources within II Kings 18-20 and (b) the historical reliability of the account of Sennacherib's invasion in II Kings 18-19. Scholars believe that the material in II Kings 18-20, particularly 18:13-20:21, is really a redacted account compiled from three different sources: 18:13-16 (Account A), 18:17-19:9a, 36-37 (Account B1) and 19:9b-35 (Account B2). Account A is generally regarded as the historically reliable account, whereas accounts B1 and B2 are considered to be theologically charged, highly legendary accounts that are not historically reliable. ${ }^{1}$

These conclusions were arrived at in the following general manner: Once it was determined that II Kings 18-20 held priority over Isaiah 36-39, scholars were faced with a problem: II Kings 18:14-16. Although II Kings 18:13 and Isaiah 36:1 corresponded with each other and although II Kings 18:17ff and Isaiah 36:2ff corresponded with each other, II Kings 18:14-16 stood entirely on its own. Since II Kings 18:13-16 seemed to coincide with what we are told about Sennacherib's invasion as recorded in the Assyrian annals, scholars concluded that II Kings 18:13-16, being verified by the Assyrian annals,

1.'Historical reliability' in this case should be understood as that which accurately reflects the historical event in question. Account A is considered 'objective history' whereas accounts B1 and B2 are essentially considered Jewish propaganda. 
was the historically reliable account. When it came to Account B, though, a further problem arose: Nothing in II Kings 18:17-19:37 seemed to make reference to Hezekiah's capitulation in II Kings 18:13-16. Given this apparent problem, scholars surmised that 'what really happened'2 during Sennacherib's invasion of 701 BCE was recorded in II Kings 18:13-16 and that II Kings 18:1719:37, since it was not verified by Sennacherib's records, was a legendary account of the event, written at a later time, possibly during the exile.

Smelik (1986:75) pointed out that further adjustments to this view came when Stade suggested that despite the fact that II Kings 18:17-19:37 was presented in the text as a unity, there was evidence of a redactor's seam in 19:9: the expression שב , ' ('and he returned'). This expression, it was argued, seemed to function as a logical beginning for B2. Based on this perceived seam, the main Sennacherib narrative was thought to be a compilation of two sources: 18:17-19:9a and 19:9b-37. It was argued that these two accounts shared close parallelism in both structure and content and that it would be highly unlikely that a single account would repeat itself to the extent found in the Sennacherib account. The only significant revision has been that of Brevard S. Childs (1967:73), who has claimed that the two accounts should be divided as follows: 18:17-19:9a, 36-37 and 19:9b-35, on the grounds that 19:36-37 provides the proper ending of B1.

The result of the prevailing scholarly view is that most think that what really happened during Sennacherib's invasion is far different from the biblical testimony concerning that event. 'What really happened' in 701 BCE was that after Sennacherib had invaded Judah in response to Hezekiah's rebellion and devastated most of Hezekiah's kingdom, Hezekiah paid tribute to Sennacherib in order to avert the destruction of Jerusalem. Sennacherib accepted Hezekiah's tribute and left Hezekiah on the throne in Jerusalem. Consequently, there was no glorious and miraculous sparing of Jerusalem by YHWH in 701 BCE. Hezekiah only survived by the skin of his teeth, and Isaiah, far from supporting Hezekiah, actually had condemned Hezekiah's rebellion. Clearly, not only is the biblical account of the invasion of Sennacherib doubted by scholars but the very biblical picture of Hezekiah himself has also come under fire.

With the issues of priority and historical reliability reserved for II Kings 18-20, the dominant questions regarding Isaiah 36-39 have tended to focus on its date of redaction and its function within Isaiah as a whole. In his work Zion's Final Destiny (1991), Christopher Seitz gives a detailed analysis of the various theories regarding the role of Isaiah 36-39 within the development of the book of Isaiah. Although there are many variations on this issue, the general scholarly consensus has been that the redaction of Isaiah 36-39 happened long after the time of Isaiah and the first 35 chapters of Proto-Isaiah. Some, such as R.E. Clements (1982:53), claim that whereas II Kings 18-20 was written during the reign of Josiah, the redaction of that material into Isaiah 36-39 happened after the composition of Isaiah 40-55 and was inserted into its present position to act as a transitional bridge between First and Second Isaiah, Chapter 39 ending with a prophecy of the coming Babylonian exile and Chapter 40 beginning with the call out of the exile. Such clear evidence of redaction has caused many scholars to argue that the material in chapters 36-39 is the product of a much later time than the events they record.

\section{The shortcomings of the current scholarship}

Despite the general consensus of scholarly opinion regarding Isaiah 36-39 and II Kings 18-20, the fact is that such views are highly questionable and deeply flawed. Not only is it decidedly not so obvious that II Kings 18-20 holds priority over Isaiah $36-39$ but it is also abundantly clear that the reasoning used to uphold the conventional belief that (a) the material in question is a compilation of three sources and that (b) the majority of this material is unhistorical and legendary is highly speculative at best.

What one quickly realises when analysing these issues is that there is an element of cause and effect at work. The ultimate cause of the debates surrounding the biblical account of Sennacherib's invasion is the assumption that II Kings 18-20 has priority over Isaiah 36-39. The effect of this assumption has been twofold: (a) The literary position of Isaiah 36-39 within the book of Isaiah was called into question and (b) the textual question of II Kings 18:13-16 brought up the question of the literary unity of II Kings 18-19 as well as the historical question concerning what really happened in $701 \mathrm{BCE}$. This has led to the division of II Kings 18:13-19:37 into two separate accounts, which, in turn, has led scholars to postulate that II Kings 18:13-16 was the true historical account and accounts B1 and B2 were simply later redacted legends of Hezekiah. This dismissal of the historical reliability of 18:17-19:37, in turn, has led to scholars questioning the historical reliability of everything in the biblical accounts of Hezekiah's reign. Over time, these assumptions have actually been put forth as evidence to support the prevailing views of (a) the priority of II Kings 18-20 and (b) the historical unreliability of accounts B1 and B2. In reality, though, what we have is a house built on sand.

As we rethink these positions, we must ask two fundamental questions: Does the evidence really point to the priority of II Kings 18-20 over Isaiah 36-39? And, is the rationale for dismissing the majority of II Kings 18-19/Isaiah 36-37 as historically unreliable truly critical and convincing? While there has undoubtedly been creative literary shaping of the text by later scribal exegetes, to simply dismiss the majority of these biblical accounts as fanciful projections by later theologically biased redactors is very simplistic, naïve and, in actuality, uncritical. Redaction and scribal exegesis does not mean that the redactors were either ignorant of the historical facts or deliberately trying to obscure them. Rather, it means that they were attempting to highlight and explain how YHWH's purpose and covenant with Israel had played out within their history. What we have in Isaiah 3639 , therefore, is the product of later 'inner-biblical' exegesis ${ }^{3}$ by scribes of the exilic period who took the core historical events and records from the time of Hezekiah, reflected on the theological significance of those events and redacted them together in order to articulate their understanding of those critical events of the Syro-Ephraimite Crisis and the invasion of Sennacherib. Although they obviously refashioned these chapters during the exile, we assert that the core story and perspective of Isaiah 3639 had its roots in the actual historical events.

\section{A question of priority: Isaiah $36-39$ or II Kings 18-20}

The first question to reconsider is whether or not II Kings 18-20 truly holds priority over Isaiah 36-39. In response to Gesenius's argument for the priority of II Kings 18-20, K.A.D. Smelik has made a compelling case for the primacy of the Isaiah text. While admitting that at first glance such a long narrative within Isaiah does seem rather odd, he argues that II Kings 18:17-20:19 does not really fit into the context of II Kings either. He points out that Isaiah is the only prophet from among the books of the Latter Prophets who appears in a narrative in Kings (1986:72). In other words, it is extremely odd that we find in II Kings such a long narrative in which Isaiah plays such an important role for the simple reason that there is nothing else like this anywhere else in the book of Kings. On the other hand, though, Smelik points out that in the book of Isaiah there are a number of narrative sections that focus on the prophet Isaiah and even points out that there is a close parallel to Isaiah 7 (1986:72). 
Yet not only is there a narrative section in Isaiah 7 where Isaiah confronts Ahaz during the Syro-Ephraimite Crisis; there is also one in Isaiah 20, set during the time of the Ashdod campaign, where Isaiah goes naked through the streets of Jerusalem for three years. Given this fact, we must consider the significance of having the three major narrative sections in Isaiah being set (a) during the very beginning of Assyria's dominance over Judah, (b) during Assyria's major military actions of the Ashdod campaign that had tremendous implications for Judah and (c) during the most significant threat to Jerusalem in 701 BCE. Given the placement of these earlier narratives in Isaiah, it should not be surprising at all to find a third narrative that tells of a major defeat of Assyria by the hand of YHWH.

We should also note the connection between the first and third narratives to the prophetic role of Isaiah. Right after the prophetic call of Isaiah in Isaiah 6, we have a narrative in Isaiah 7 of Isaiah's first recorded prophetic action: his appeal to Ahaz to put his faith in YHWH during the Syro-Ephraimite Crisis and Ahaz's subsequent lack of faith in YHWH. Proto-Isaiah then ends with yet another narrative in Isaiah 36-39, one of Isaiah's last recorded prophetic actions: his advising Hezekiah to put his faith in YHWH during the time of Sennacherib's invasion. By contrast, the narrative of Sennacherib's invasion within II Kings seems to be unusually long compared to other narratives of other kings found in the book of Kings. It seems much more likely that II Kings 18:1-12 contains material more in line with the other material found throughout the book of Kings, whereas 18:14-16, either copied from another unknown source or written by the redactor himself, was interwoven with Isaiah's narrative into the larger narrative unit of 18:13-20:19, only to be concluded with the standard conclusion found in the book of Kings in 20:20-21.

The argument that the writer of the book of Kings borrowed this material from Proto-Isaiah is further strengthened by following the general rules of textual criticism. It is more likely that a later text adds to an original text rather than subtracts from it. Yes, it is also possible to argue that the most difficult reading is usually the earlier reading and that II Kings $18-20$ is more difficult than Isaiah 36-39, but we must ask, What is it that makes it more difficult? Is it a corruption in the text or rather scholarly ignorance and misunderstanding of the literary artistry of the scribal exegetes? A simple glance at the parallel Sennacherib accounts in Isaiah 36-37 and II Kings 18-19 will show that the latter is true.

Upon looking at the parallel texts of Isaiah 36-37 and II Kings 1819 , one can see that these 'parallel' accounts are not completely identical. Firstly, II Kings 18:1-12, a section clearly in the mould of how other kings throughout II Kings are summarised, is unique to II Kings. In it, we are told about the fall of Samaria during the early part of Hezekiah's reign. As scholars have pointed out, there is a clear shaping of this material along the Deuteronomist's view of the history of Israel: bad kings break covenant with YHWH and good kings keep covenant with YHWH. Secondly, II Kings 18:14-16, a brief section that one can argue was inserted between what was originally Isaiah $36: 1$ and 36:2, is also unique to II Kings. It tells about Hezekiah's payment of tribute to the king of Assyria in an attempt to spare Jerusalem from destruction at the hands of Sennacherib. Finally, there are a number of variants found in the II Kings narrative that can best be described as minor elaborations on the Isaiah narrative. Virtually every instance where there is a small variation, we see that the text in II Kings expands and elaborates on the Isaiah text. For example, one can see why in II Kings 18:36 the writer would elaborate on Isaiah 36:21 and clarify that the 'they' in Isaiah 36:21 is a reference to 'the people' as a whole and not just Eliakim, Shebna, and Joah, but it would not make sense that the writer of Isaiah would take a clear reference to 'the people' in II Kings 18:36 and make it more ambiguous in Isaiah 36:21.

One can reasonably deduce from these facts that the writer of II Kings got his material of 18:1-12 and 18:14-16 from an original source, probably that of the Annals of the Kings of Judah, and then incorporated the material he borrowed from Isaiah 36-39 into his narrative about Hezekiah. The reason for this could very well be that the story of Hezekiah was already so important within Jewish history that the writer felt it was important to give extra attention to Hezekiah within the book of Kings. Yet if Isaiah had copied from the book of Kings, one has to wonder why he (a) chose not to include II Kings 18:1-12 and why he (b) chose to use 18:13, exclude II Kings 18:14-16 and then pick up the story again at 18:17. Simply put, given Hezekiah's status in Jewish history, it would make sense for the writer of the book of Kings to add the Hezekiah material from Proto-Isaiah yet it would not make sense for the writer of Proto-Isaiah to omit part of the Hezekiah narrative in II Kings.

A final point must be made. We must also remember that the Sennacherib account of Isaiah 36-37 is not the only narrative that is shared by Isaiah and II Kings. There are also the accounts of Hezekiah's illness (Isaiah 38/II Kings 20:1-11) and of the visit from the envoys from Babylon (Isaiah 39/II Kings 20:12-19). These twin episodes are clearly out of chronological order. It simply does not make chronological sense for Isaiah to tell Hezekiah that Jerusalem will be delivered from the hand of the king of Assyria (38:6) when it has just taken place in Chapter 37. Scholars such as Peter Ackroyd (1982:3-21) and Christopher R. Seitz (1991) have rightly noted that the placement of Isaiah 38-39 after Isaiah 36-37 acts as an editorial bridge between Proto- and Deutero-Isaiah, thus playing an important role in the literary structure of Isaiah. One can see why Proto-Isaiah would be concluded with the narrative about the envoys from Babylon: they foreshadow the Babylonian exile that is addressed in Chapter 40. Yet there is no logical reason as to why the book of Kings, a narrative that chronologically takes us through the reigns of the kings of both Israel and Judah, would place an episode like the visit from the envoys of Babylon so clearly out of chronological order.

It is, of course, quite possible that both Isaiah and II Kings borrowed the material in question from an earlier unnamed source completely lost to us. Perhaps this 'original account' was comprised of what is found in II Kings 18:13-20:21 and the writer of Isaiah chose to exclude the material that is now II Kings 14-16; perhaps it was comprised of what is found in Isaiah 36-39 and the writer of II Kings chose to add the material that is now II Kings 18:14-16 and to clarify a number of things throughout the account. The fact is that we simply cannot know for certain. What we do know, though, is that the argument for the priority of II Kings $18-20$ is by no means a strong argument and to base so much scholarly work on such a weak argument is highly questionable.

Nevertheless, we are still inclined to take the position that Isaiah 36-39 holds priority over II Kings 18-20 for two reasons: First, the earlier source hypothesis is an argument from silence. There simply is no way to verify the claim that there was an earlier source. It is a possibility that only gains credibility if both of the other two possible explanations fail to convince. This brings us to the second reason. Not only on textual grounds does it seem that II Kings 18-20 expanded the material found in Isaiah 36-39, but from a literary point of view, the material in question also fits much better into the literary structure of Isaiah, not II Kings. It is to this point we will now turn our attention.

\section{The literary unity of Isaiah 36-39}

In contrast to scholars such as Stade and Childs, Smelik suggests that when read from a literary point of view, Isaiah 36-37 does not so much point toward two separate accounts that have been redacted together but rather to a highly stylised account that uses repetition as a literary device. 'Repetition', Smelik (1986:76) argues, 'is a common phenomenon in biblical narrative' and such repetition 'need not indicate a combination of earlier sources'. Smelik makes his argument by pointing to a 
number of examples of three-fold repetition in the Sennacherib account.

The first example can be found in the three Assyrian messages found within the account: (a) the Rabshakeh's first speech, (b) the Rabshakeh's second speech and (c) Sennacherib's letter. The prevailing scholarly opinion sees Sennacherib's letter as a duplicate of the prior two speeches of the Rabshakeh and therefore assign it to Account B2. Smelik, though, points out the three-fold nature of the Assyrian taunts. In the Rabshakeh's first speech, he tries to convince Hezekiah that he has no one to rely on; in the Rabshakeh's second speech, he tries to separate the people of Judah from their king; and in Sennacherib's letter, he tries to separate Hezekiah from YHWH and ends up by calling YHWH a deceiver. Smelik's point is simple:

These three messages are not duplicates: each has its own function in the narrative and together they enhance the suspense in the narrative: will the Assyrian king taunt the Living God with impunity.

(Smelik 1986:81)

The second example can be seen in Isaiah's three oracles found in 37:6-7, 37:22-29 and 37:33-35. Each oracle is vital to understanding the overall structure of the Sennacherib narrative. In 37:6-7 YHWH says that he will 'put a spirit' in Sennacherib and that Sennacherib will 'hear something to hear' (i.e. a rumour or report), return to his land and then fall by the sword. This ambiguous oracle presents a number of questions the reader must wait to get answers for. It does not take long, though, for the reader to understand what kind of spirit YHWH will put in Sennacherib. This spirit is not so much a spirit of panic as it is a spirit of pride (1986:83). We know this, Smelik argues, because of what comes next in 37:8-9: a three-fold repetition of the phrase 'he heard', the last of which Stade ironically characterised as a 'seam' between accounts B1 and B2. In 37:8 we find that the Rabshakeh 'heard' that Sennacherib had left Lachish to fight against Libnah. Why did Sennacherib do this? We learn in 37:9 that Sennacherib 'heard' that King Tirhakah had come out to fight against him. We are further told that when Sennacherib 'heard' about this move by King Tirhakah, he sent messengers to Hezekiah with a letter in which he further threatens Hezekiah with the third message. Now Stade and Childs, by assuming that there is a seam in $37: 9 b$, would have us think that in the B1 account, when Sennacherib 'heard' about the Egyptian threat, he was filled with a spirit of panic and returned to his own land, only to be killed later on (37:37-38). This would seem quite an odd move on the part of Sennacherib, given the fact that the Rabshakeh had mocked Egypt's ability to help Hezekiah earlier in 36:6, 9. Simply put, the proposed reading of B1 does not make sense. If taken as a literary unity, though, the picture becomes quite clear. Smelik argues:

Instead of withdrawing, Sennacherib continues to taunt the Living God. It is not the Egyptian ally who will silence the Assyrian king, but the Lord Himself, as appears only at the very end of the narrative. By supposing that in the first account the news of Tirhakah's arrival ended Sennacherib's attack, Stade actually walked into the trap the author has set for the reader.

(Smelik 1986:77)

By the end of the narrative, we see precisely how this first oracle has been fulfilled. YHWH was able to use the very Egyptian alliance that Isaiah had earlier condemned by using it to ignite a spirit of pride and arrogance on Sennacherib's part, which caused him to further taunt $\mathrm{YHWH}$, which ultimately led to his humiliation and death.

In the second oracle, found in 37:22-29, we find YHWH's condemnation of Sennacherib's arrogance (so clearly displayed by the Rabshakeh's two speeches and Sennacherib's mocking letter to Hezekiah), and the prophecy that YHWH will turn Sennacherib back on the way by which he came. Not only does this second oracle build on the first oracle and Sennacherib's blasphemous taunting letter to Hezekiah but it also looks forward to Sennacherib's humiliating failure. The third oracle, found in 37:33-35, elaborates on the second oracle by specifically saying that Sennacherib's army would not even shoot an arrow into Jerusalem, let alone enter it, and that he would return by the way by which he came. The reason for this would not be because of some spectacular military defence by Hezekiah or Tirhakah or any other human king. We are told in this third oracle that YHWH would defend Jerusalem.

All three of these oracles find their fulfilment in Isaiah 37:36-38. These final verses of the Sennacherib narrative 'allude to the three oracles together. Therefore it is impossible to divide these verses into two strands without serious exegetical loss' (Smelik 1986:84). Smelik's literary reading of the Sennacherib account in Isaiah is a convincing argument for its literary unity that makes sense at every point in the narrative. By contrast, the arguments of scholars such as Gesenius, Stade, Childs and Clements appear to be rather convoluted, confusing and ultimately incomprehensible.

\section{The occasion and purpose of Isaiah 36-39}

Despite Smelik's convincing argument concerning the literary unity of Isaiah 36-39 and its priority over II Kings 18-20, there still remains the question as to when and for what purpose this material was written. While it is true that no one is able to put forth a specific date for the composition of either books of Kings or Isaiah, the book of Kings is believed to have been written anywhere between $561 \mathrm{BCE}$, the last date mentioned in II Kings (when Jehoaichin was released from captivity), and $538 \mathrm{BCE}$ the date when Cyrus the Great declared that the Jews were free to return to their homeland. Furthermore, not only does Jewish tradition hold that Jeremiah was the writer of the book of Kings, many scholars have also speculated that the Deuteronomist was, in fact, Jeremiah. Even if this is so, it is still acknowledged that the book of Kings underwent revision during the exilic period.

The book of Isaiah, though, tends to be a bit more complex. On the one hand, there is virtually universal agreement concerning the division of Isaiah into at least two parts: Proto-Isaiah (chapters 1-39) and Deutero-Isaiah (chapters 40-66). The reason for this is that whereas Chapter 39 ends with the reign of Hezekiah and looks ahead to the Babylonian exile, Chapter 40 begins with a prophetic call to come out of the Babylonian exile. Given the fact that the last certain event in Hezekiah's reign was Sennacherib's invasion in $701 \mathrm{BCE}$ and the end of the exile came about with Cyrus' decree in $538 \mathrm{BCE}$, it is impossible that one person could have written the entirety of the book of Isaiah. Most scholars attribute the bulk of Proto-Isaiah to the original prophet Isaiah who lived during the eighth century BCE in Jerusalem and Deutero-Isaiah to later exilic and post-exilic writers. As with the book of Kings, the book of Isaiah is seen to have also passed through a number of redactions.

Beyond these general dates, though, not much more can be definitely said concerning the dates of composition of the book of Kings and the book of Isaiah. Given this fact, it is extremely odd that so many scholars have quickly assumed that the book of Kings was composed before the book of Isaiah. If anything, the evidence points in the opposite direction. First, it is generally acknowledged that the bulk of Isaiah 1-39 has its roots in the original prophet Isaiah himself. The opening verse of Isaiah mentions Uzziah, Jotham, Ahaz and Hezekiah ${ }^{4}$ and thus is a clear indication that chapters 1-39 should be seen as a unit. Isaiah 6 marks the beginning of Isaiah's prophetic ministry in the year King Uzziah died, and Isaiah 36-39 recounts the events of Hezekiah's reign. Yet then there is a gap from roughly 701 BCE to 537 BCE between Isaiah 39 and 40, with no mention of Manasseh, Josiah or the fall of Jerusalem in 587 BCE. It seems quite logical, therefore, to attribute Isaiah $40-66$ to later exilic 4.The proposed dates for the reigns of these kings are generally the following: Uz-
ziah (811-759 BCE), Jotham (758-742 BCE), Ahaz (742-727 BCE) and Hezekiah (727-698 BCE). 
scribes who prophesied and wrote in Isaiah's name. The clear impression in Isaiah is that chapters 1-39 originated in the eighth century BCE.

The book of Kings, on the other hand, records the reigns of the kings of Israel and Judah right up to the time of the Babylonian exile of 587 BCE. Furthermore, throughout the book of Kings there is a familiar refrain that tells the reader that if he or she cares to know more about any particular king that information is given in either the Annals of the Kings of Israel or the Annals of the Kings of Judah. The book of Kings, therefore, was clearly written after 587 BCE. This definitively places the composition of the book of Kings either during or after the exile, long after the composition of Proto-Isaiah. While there is no doubt that the books of Kings and Isaiah underwent redaction during the exile, one thing is clear: The scribal exegetes of the book of Isaiah took an already existing Proto-Isaiah and shaped it into the present final form of Isaiah 1-39 to fit in with what was written in the exilic work of Deutero-Isaiah. The redactor of the book of Kings, on the other hand, composed his work by taking sections from the Annals of the Kings of Israel and Judah and redacting them within his own exilic composition. Therefore, if we know that he used earlier pre-exilic works and that Proto-Isaiah was also preexilic, it is reasonable to assume that the writer of Kings could very well have borrowed chapters 36-39 from Proto-Isaiah as well.

We also must take into consideration the fact that the writer of Chronicles makes reference to the book of Isaiah. When summing up his narrative about Hezekiah, the writer of II Chronicles states in 32:32 that the other events in Hezekiah's reign 'are in the visions of the prophet Isaiah son of Amoz and in the book of the kings of Judah and Israel' (NJPS). Two points can be made here. First, this 'book of the kings of Judah and Israel' is not a reference to the book of Kings but rather to the source that both the writer of the book of Kings and the writer of the book of Chronicles referred to when writing their respective works. What this shows is that since Isaiah in some form (i.e. Proto-Isaiah) was circulated in the exilic community along with the royal annals of Judah and Israel, it was clearly composed before the exile. Second, we must acknowledge that the fact that the Sennacherib account in II Chronicles shares the same basic storyline as Isaiah 36-37 is still further indication that the pre-exilic Proto-Isaiah already contained the account of Sennacherib's invasion found in Isaiah 36-37. Hence, the material in Isaiah 36-39, though probably shaped by the exilic community to act as a literary bridge to Isaiah 40-66, was nevertheless already present in Proto-Isaiah; it was not added by the exilic community. Furthermore, since II Chronicles borrowed from the book of [Proto]-Isaiah, there is no reason to doubt that it could have been used in a similar fashion by the writer of the book of Kings. One can logically allow for the possibility that the writer of Kings had Isaiah 1-39 in some form at his disposal as he compiled his own work.

This leaves one final question: When specifically was Isaiah 36-39 most likely written? In his book Zion's Final Destiny, Christopher Seitz (1991), after analysing the work of many scholars who have wrestled with the issue of the occasion, purpose, place and function of Isaiah 36-39, asserts that the events described in Isaiah 36-39 have their historical roots within the reign of Hezekiah and that the initial recording of these chapters might have very well happened during the reign of Manasseh, shortly after the reign of Hezekiah, during the later years of the prophet Isaiah himself. ${ }^{5}$ This proposal is more convincing than the prevailing scholarly opinion for three reasons: First, the way in which history is presented in Isaiah indicates that Isaiah 36-39 is to be viewed as a part of Proto-Isaiah. The setting of Isaiah 36-39

5.Seitz, Zion's Final Destiny. 'I see no reason to date the narrative in its present form much ' much later than the death of Sennacherib (681), with which it comes to a stunning close' (117) 'Hez exilic period, but is of a piece with 8.23-9.6, 11:1-10, and 32.1-8. In sum, a strong possibility exists that the initial editorial work on Isaiah traditions came not during the period of Josiah (who is never mentioned in the book), but during the reign of Hezekiah, at the end of Isaiah's own lifetime' (61) is clearly during the lifetimes of Isaiah and Hezekiah, whereas the setting of Isaiah 40-66 is clearly that of post-exilic Judah.

Second, a more plausible historical reconstruction of the events that brought about the writing of Isaiah 36-39 can be made than the reconstructions of scholars such as Clements who has argued that despite Hezekiah's humiliating defeat in $701 \mathrm{BCE}$, the writer of II Kings 18-20 was able to rewrite history and portray it as a glorious victory for Hezekiah for the sole purpose of encouraging Josiah to rebel against Assyria. Upon reflection, we see that this proposal simply pushes the bounds of believability. Indeed, it is decidedly unbelievable to think that Josiah could be so oblivious to such a national tragedy during the reign of his great-grandfather that he would launch a full-scale revolt against the most powerful empire in the world based on a blatantly false account of the history of Sennacherib's invasion.

By contrast, a much more likely historical scenario for the composition of Isaiah 36-39 is that of the time shortly after Sennacherib's invasion and Hezekiah's death, somewhat early on during the reign of Manasseh. Sennacherib's invasion of Judah in 701 BCE was no doubt a monumental event in the history of Judah. Both the biblical accounts as well as Sennacherib's own annals testify that Sennacherib wreaked havoc throughout the Judean countryside, devastated 46 towns in Judah and holed Hezekiah up in Jerusalem. Nevertheless, Hezekiah somehow survived and Jerusalem did not fall. If one were able to travel back in time and witness the fallout from Sennacherib's invasion, one would probably find that opinion was divided over what had happened. Although Jerusalem survived, much of Judah was devastated. By no means would this have been considered a clear-cut cause of rejoicing.

There were obviously some in Judah, as can be seen reflected in the actions of Manasseh, who not only viewed Isaiah as a troublemaker for insisting on the sole worship of YHWH but who also saw Hezekiah as a foolish king who had brought disaster on Judah by getting rid of the high places and by provoking Sennacherib. They would have looked at the destruction throughout Judah and concluded that it was because of Hezekiah's fanatical devotion to YHWH alone and his subsequent demolition of the gods that his father Ahaz had worshipped that this 'disaster' happened. It should come as no surprise, therefore, to find that after Hezekiah's death, Manasseh sought to re-establish the worship of the very gods whose images Hezekiah had destroyed. He obviously was one of those who viewed Sennacherib's invasion as a disaster for Judah. His idolatry, therefore, could be seen as an attempt to win the favour of the gods again.

Yet there were obviously others in Judah, as can be seen reflected in Proto-Isaiah, who saw Isaiah as a true prophet of YHWH and Hezekiah as a righteous king who had been vindicated by YHWH for his whole-hearted devotion to the one true God of Israel. They would have obviously seen Manasseh's actions as sinful and idolatrous. They interpreted Sennacherib's failure and YHWH's faithfulness to Jerusalem as a fulfilment of what Isaiah had prophesied during the Syro-Ephraimite Crisis, in chapters $7-12$. It is this interpretation of 701 BCE we see reflected in Proto-Isaiah and shaped within what can be deemed the 'literary bookends' of Isaiah 7-12 and 36-39.

The question stemming from these events would undoubtedly become, 'Which interpretation of these historical events would win out in the collective memory of the Jewish people?' The honest consideration of this question opens the door to dating the composition of Isaiah 36-39 shortly after the death of Hezekiah and early on within the reign of Manasseh. In reaction to Manasseh's idolatrous policies, disciples of Isaiah or scribal exegetes faithful to YHWH composed Isaiah 36-39 to counter the view put forth by Manasseh's government that Sennacherib's invasion happened because Hezekiah foolishly destroyed the idols of the other gods in Judah and chose to trust in YHWH, the 
God of Isaiah, alone. By contrast, these Isaianic scribes faithful to YHWH sought to vindicate (a) Isaiah's prophetic career, (b) Hezekiah as a faithful and righteous king and (c) YHWH as the true God who was faithful to Judah and who would continue to be faithful to Judah.

This proposed scenario regarding the composition of both Isaiah 36-37 and Proto-Isaiah as a whole seems much more plausible than either a Josianic or exilic scenario. Neither view allows any room for debate on the interpretation of the historical events surrounding Sennacherib's invasion. Both assume that everyone initially viewed Sennacherib's invasion as a complete disaster for Judah and that the text of Isaiah 36-37/II Kings 18-19 is nothing more than a later rewriting of history by theologically motivated and highly biased redactors. Neither view acknowledges that such a major event would have invoked drastically different interpretations as soon the dust had settled and people started asking, What happened? Simply put, neither view is realistic. By contrast, dating the composition of Isaiah 36-37 and the formulation of Proto-Isaiah shortly after Hezekiah's death, early on in Manasseh's reign, seems infinitely more plausible. The battle over the interpretation of such a major event as Sennacherib's invasion would have been fought shortly after the event had taken place, not 200 years later.

A third reason why dating Isaiah 36-39 shortly after Hezekiah's reign is more plausible is that it is essential to the literary structure of Proto-Isaiah. Not only does such an argument provide a credible historical setting in which the formation of Proto-Isaiah possibly came about but inclusion of chapters 36-39 within Proto-Isaiah also helps us understand the literary structure and purpose of Proto-Isaiah. Our position is that chapters 7-12 and 36-39 act as 'literary bookends' that highlight not simply contrasting pictures of Ahaz and Hezekiah but the origin and fulfilment of the Immanuel prophecies. In response to Ahaz's failure to put his faith in $\mathrm{YHWH}$, Isaiah had not only prophesied the coming Assyrian oppression but had also prophesied about the faithfulness and righteousness of Immanuel - Ahaz's son, the royal heir and the future king - the one through whom YHWH would bring about the deliverance of the remnant of Judah and the humiliation of Assyria. Immanuel, within the context of Proto-Isaiah, is none other than Hezekiah. The entire literary structure and purpose of Proto-Isaiah point to this end; the historical setting in which this would be an issue would the time shortly after Hezekiah's death when Manasseh was bent on re-establishing pagan worship.

\section{The reliability of the biblical accounts of Sennacherib's invasion}

Even if one is convinced by the above argument regarding the date and occasion of Isaiah 36-39, one might still question the historical reliability of these chapters. There are essentially three reasons why these chapters are considered to be unhistorical and legendary. First, as already discussed earlier, scholars point to the correlation between II Kings 18:13-16 and the Assyrian annals as proof of its historical reliability and by extension the historical unreliability of II Kings 18:17-20:19/Isaiah 36-39. The second reason is that the biblical account credits the salvation of Jerusalem to an angel of YHWH destroying 185000 Assyrian soldiers outside the walls of Jerusalem in one night. Most scholars dismiss this 'miracle' as a later legendary account that offends our modern sensibilities and that simply could not be historical. A third reason is that many think these accounts are too theologically motivated to be considered historically reliable.

If we analyse these objections, though, we quickly see that they are unfounded. The first reason simply betrays an underlying prejudice in favour of the Assyrian annals and against the biblical text. This assumption - that the biblical text is theologically biased whereas the Assyrian records are objective, thus the only part of the biblical text that can be trusted is that which correlates with the Assyrian account - is utterly wrong-minded. As Iain Provan (2000) points out in his article In the Stable with the Dwarves, both accounts are ideological accounts of the past that try to interpret certain events from their particular point of view. Both accounts have an 'agenda', if you will. If the biblical text is trying to show that Hezekiah is a faithful and righteous king and that $\mathrm{YHWH}$ is the one true God, we must also realise that the Assyrian annals are trying to 'to exalt the reputation of the king concerned, to glorify the gods of Assyria, especially Ashur, and to encourage loyalty and submission among his subjects (Provan 2000:31). This is precisely what we see when we look at Sennacherib's version of the events of 701 BCE. Therefore, since it is clear that Sennacherib had his own agenda to push, we must wonder why scholars chose to doubt the biblical version of events and not Sennacherib's version.

The scholar must look at both accounts and, while fully realising that both accounts are told from different ideological perspectives and agendas, attempt to come to some sort of conclusion about the historical event in question. When one considers both accounts, one sees that they agree on four points: (a) Sennacherib invaded and took many fortified cities in Judah; (b) Sennacherib besieged Jerusalem and Hezekiah seemed completely helpless; (c) the Egyptian army at some point appeared and was dealt with; and (d) Hezekiah eventually paid tribute to Sennacherib. Nothing in the larger biblical account contradicts any of these four points The only glaring difference between the biblical account and Sennacherib's version is, not surprisingly, the conclusion to the matter: The biblical account claims an 'angel of YHWH' destroyed 185000 Assyrian soldiers, Sennacherib withdrew and Jerusalem was spared; Sennacherib's version makes no mention of this. Yet for that matter, it is very interesting to note that Sennacherib conveniently never tells of the outcome of his siege of Jerusalem. All he mentions is that Hezekiah sent him tribute once he had returned to Nineveh, where he celebrated the siege and capture of Lachish, not Jerusalem. In fact, Alan Millard points out that the Lachish Room 'stands as the focus of the whole section of the palace' (1985:68). Despite the fact that Jerusalem was the capital, there is surprisingly no celebration over its capture or any mention of the siege of Jerusalem. Sennacherib does not even mention that he has chosen to spare Jerusalem.

We, therefore, have very good reason to be suspicious of Sennacherib's version of events. Why did Hezekiah send him tribute not outside Jerusalem, not at Lachish, but only later, after Sennacherib had returned to Nineveh? Why did Sennacherib highlight the siege at Lachish and conveniently push Jerusalem to the background? Why, if Hezekiah was the rebel ruler and instigator of the revolt, did Sennacherib choose to leave him on the throne, only requiring tribute? Finally, while it is true that Sennacherib claims victory in his annals, it is, as Millard notes, 'muted in comparison with the ending of every other one of Sennacherib's campaigns in which he proclaims what he has done' (1985:71-72). Furthermore, Antti Laato adds that the list of tribute sent by Hezekiah was meant to 'give the impression that [Sennacherib's] campaign in Judah had been successfully concluded, even though Hezekiah, the main rebel, was not dethroned' (1995:218). Upon further reflection, Sennacherib's 'objective' account does not seem to be too objective after all.

The second reason why scholars discount Isaiah $36-37$ as legendary centres on the claim that an angel of YHWH killed 185000 Assyrian soldiers. Yet not only is it questionable to dismiss the entire account because of one verse but such an action also displays a shocking amount of literary ignorance. It does not allow any room for metaphor, symbolism or creative licence in the story. Now, it is very reasonable to ask the question, 'Was there a literal angel who struck down 185000 Assyrians?' For that matter, it is very reasonable to ask other questions, such as, 'Did the Rabshakeh really say those exact words in the speech accredited to him?' 'Did Hezekiah really say that exact prayer?' 'Did Isaiah really utter that prophecy, word for word?' The obvious answer to all of these questions is, 'Of course not.' But 
that does not mean that the Rabshakeh did not taunt Hezekiah in some way; that does not mean that Hezekiah did not offer up a prayer to $\mathrm{YHWH}$ for deliverance; that does not mean Isaiah did not prophesy that YHWH would save Jerusalem; and that does not mean that something quite unusual did not happen that caused the Assyrian army to abandon the siege of Jerusalem and that was interpreted by the people of Judah as an act of YHWH. One thing is clear: Something happened that caused Sennacherib to call off the siege. The biblical account interprets this 'something' as an act of God; Herodotus and Josephus suggest that it was some sort of plague, and indeed that may very well be the case. We simply do not know. All we know is that Jerusalem was spared and Hezekiah stayed on the throne. The biblical testimony presents this event as the glorious deliverance of Jerusalem by YHWH while Sennacherib's account glosses over and sidesteps the siege of Jerusalem every chance he gets. Must we believe that there was a literal angel who killed 185000 Assyrian soldiers? No. Does this mean we must dismiss the entire account as legendary and unhistorical? No. All it means is that we need to use our common sense and be able to recognise literary artistry and metaphor when it appears in a text that relates historical events.

Finally, there is the objection that we cannot believe the biblical portrait of Hezekiah because these stories were written during the exilic period. Yet we have put forth evidence that date ProtoIsaiah to the time shortly after Hezekiah's reign. And even though the material in Proto-Isaiah underwent redaction and literary styling during exilic and post-exilic times, we must be cautious when we attempt to put forward the argument that large sections in Proto-Isaiah were essentially made up out of whole cloth by later redactors and therefore have no historical basis to them.

Contrary to many modern scholars who try to caricature the biblical accounts of Sennacherib's invasions as a legendary 'pie in the sky' account that inaccurately portrays Hezekiah as an ideal king who could do no wrong, a clear reading of the biblical accounts gives no such impression. The biblical account gives a very honest and straightforward account of Sennacherib's invasion. Firstly, there are a number of passages in Isaiah that clearly condemn rebellion and reliance on Egypt, both of which Hezekiah seemed to have done at some point in his reign (Is $30: 1-3 ; 31: 1-3 ; 36: 2,9)$. Secondly, we are told how Sennacherib captured all of Judah's fortified cities and how many deserted Hezekiah as well. Third, the episode concerning the envoys from Babylon highlights a major blunder on Hezekiah's part as well. The biblical account clearly does not shy away from the negatives during Hezekiah's reign. Nevertheless, we are told that in $701 \mathrm{BCE}$, when Sennacherib was on the verge of destroying Jerusalem, Hezekiah, despite his past flaws, displayed great faith in $\mathrm{YHWH}$ and that Jerusalem was indeed spared.

\section{Final thoughts on Isaiah 36-39 and the occasion for Proto-Isaiah}

The essential problem with historical-critical biblical scholarship is that too often scholars simply cannot fathom the possibility that the biblical writers, or any writer for that matter, could employ literary artistry and still present a historically reliable account of the past. This divorce between literary concerns and history simply destroys any meaningful exegesis and understanding of the text. The task of the exegete is to come to a clearer understanding of Israelite history through the biblical texts, not despite them. We have shown in this article that the generally accepted opinion that rejects the historical reliability of the biblical accounts of Sennacherib's invasion is not only ill-founded and highly questionable but it also ultimately obscures any clear exegetical understanding and vision of the literary structure of Proto-Isaiah. We have analysed the details of the literary structure of Isaiah 36-39, have addressed the issue of priority and have concluded that it is more likely that Isaiah 36-39 holds priority over II Kings 18-
20. We have also argued that Isaiah 36-39 should be accepted as containing historically reliable information that can be traced back to the tumultuous early days of Manasseh, whose policies reflect that he clearly viewed Hezekiah as a foolish king and Isaiah as a false prophet.

Scholars rightly note that Isaiah 36-39 attempts to put Hezekiah forth as an ideal king. It is also true that Hezekiah and Ahaz are portrayed as opposites in terms of faithfulness to YHWH. Yet we are mistaken if we assume that these chapters are somehow historically unreliable. What we have in both Isaiah 36-39 and Isaiah 7-12 is not 'history' per se but theological interpretations of real historical events. They are about real events in history and not simply later projections that have no basis in history. The scribal exegetes who compiled Proto-Isaiah were not interested in abstract theological concepts. They were concerned with showing how the God of Israel had indeed worked in the life and times of their beloved king and their revered prophet. Therefore, their 'literary work' of Proto-Isaiah was intimately tied to historical events and ultimately addressed what was for them a hotly debated current controversy as to how to interpret those historical events.

\section{REFERENCES}

Ackroyd, P.R., 1982, 'Isaiah 36-39: Structure and function', in W.C. Delsman (ed.), Von Kanaan bis Kerala: Festschrift fur Prof. Mag. Dr. J.P.M. van der Ploeg, O.P. zur Vollendung des siebxigsten Lebensjahres am 4 Juli 1979, pp. 3-21, Neukirchener Verlag, Neukirchen-Vluyn.

Ackroyd, P.R., 1984, 'The biblical interpretation of the reigns of Ahaz and Hezekiah', in W.B. Barrick \& J.R. Spencer (eds.), In the shelter of Elyon, pp. 247-59, JSOT Press, Sheffield.

Childs, B.S., 1967, 'Isaiah and the Assyrian crisis', Studies in Biblical Theology, second series 3, Naperville, Alec R. Allenson.

Childs, B.S., 2001, Isaiah, Westminster/John Knox Press, Louisville.

Clements, R.E., 1980, 'Isaiah and the deliverance of Jerusalem: A study of the interpretation of prophecy in the Old Testament', Journal for the Study of the Old Testament suppl. 13.

Clements, R.E., 1982, 'The unity of the book of Isaiah', Interpretation 36, 117-129.

Fishbane, M., 1985, Biblical interpretation in ancient Israel, Clarendon, Oxford.

Laato, A., 1995, 'Assyrian propaganda and the falsification of history in the royal inscriptions of Sennacherib', Vetus Testamentum 45(2), 198-226.

Millard, A.R., 1985, 'Sennacherib's attack on Hezekiah', Tyndale Bulletin 36, 61-77.

Person, R.F. Jr., 1999, 'II Kings 18-20 and Isaiah 36-39: A text critical case study in the redaction history of the book of Isaiah', Zeitschrift fur die Alttestamentliche Wissenschaft, 111, 373-379.

Provan, I.W., 1988, 'In the stable with the dwarves', in A. Lemaire \& M. Saebo (eds.), Congress volume, pp. 281-320, Brill, Boston.

Provan, I.W., 1995, 'Ideologies, literary and critical: Reflections on recent writing on the history of Israel', Journal of Biblical Literature 114(4), 585-606.

Provan, I.W., Philips Long, V. \& Longman, T. III., 2003, A biblical history of Israel, Westminster/John Knox Press, Louisville.

Rowley, H.H., 1963, 'Hezekiah's reform and rebellion', in H.H. Rowley (ed.), Men of God, pp. 98-132, London, Thomas Nelson and Sons.

Seitz, C.R., 1991, Zion's final destiny: The development of the book of Isaiah: A reassessment of Isaiah 36-39, Fortress Press, Minneapolis.

Smelik, K.A.D., 1986, 'Distortion of Old Testament prophecy: The purpose of Isaiah 36 and 37', in J. De Moor (ed.), Crises and perspectives, pp. 70-93, E.J. Brill, Leiden. 